\title{
Jurist-Diction
}

Volume 3 No. 5, September 2020

\section{Tenaga Kesehatan yang Berwenang Melakukan Tindakan Aborsi Legal}

\author{
Risa Noviariyani \\ Noviariyanirisa@gmail.com \\ Universitas Airlangga
}

How to cite:

Risa Noviariyani, 'Tenaga

Kesehatan yang Berwenang Melakukan Tindakan Aborsi Legal' (2020) Vol. 3 No. 5

Jurist-Diction.

Histori artikel:

Submit 8 Juli 2020;

Diterima 14 Agustus 2020;

Diterbitkan 1 September 2020.

DOI:

10.20473/jd.v3i5.21985

\begin{abstract}
Abstrak
Aborsi adalah tindakan untuk mengakhiri kehamilan dengan mengeluarkan hasil konsepsi sebelum janin dapat hidup diluar kandungan yang pada dasarnya di larang di Indonesia. Dalam Kitab undang-undang hukum pidana pengaturan mengenai aborsi masuk dalam bab kejahatan terhadap nyawa. Meningkatnya Angka kematian Ibu karena praktek aborsi yang dilakukan dengan tidak aman dan tidak dilakukan oleh tenaga kesehatan yang berwenang melakukan tindakan aborsi. Alasan tersebut yang kemudian memunculkan adanya pengecualian larangan aborsi, yakni pada pasal 75 ayat (2) Undangundang Nomor 36 tahun 2009 tentang Kesehatan, menyatakan bahwa aborsi boleh dilakukan dengan alasan kedaruratan medis dan kehamilan akibat pemerkosaaan. Tindakan aborsi sebagaimana yang dimaksud pada pasal 75 hanya dapat dilakukan oleh Tenaga Kesehatan yang memiliki sertifikat yang di tetapkan oleh menteri, namun dalam hal ini pasal tersebut tidak menjelaskan mengenai kualifikasi siapa saja Tenaga Kesehatan yang berwenang melakukan tindakan aborsi karena Tenaga Kesehatan dibedakan menjadi beberapa macam berdasarkan Undang-Undang Tenaga Kesehatan. Adapun tujuan dari skripsi ini yaitu untuk mengetahui siapa saja tenaga kesehatan yang berwenang melakukan tindakan aborsi legal. Untuk mendapatkan jawaban atas permasalahan tersebut digunakan pendekatan peraturan perundangundangan dan pendekatan konseptual, yang dengan pendekatan tersebut dapat di tarik kesimpulan bahwa tenaga kesehatan yang berwenang melakukan tindakan aborsi legal ialah dokter berdasarkan Peraturan Menteri Kesehatan Nomer 3 Tahun 2016 Tentang Pelatihan dan Penyelenggaraan Pelayanan Aborsi atas Indikasi Kedaruratan Medis dan Kehamilan Akibat Perkosaan.

Kata Kunci: Aborsi; Tenaga Kesehatan; Dokter.
\end{abstract}

\section{Pendahuluan}

Aborsi selalu menjadi topik perbincangan yang menarik, baik dalam forum resmi maupun tidak resmi yang menyangkut bidang kedokteran, pendidikan, hukum, sosial dan ilmu disiplin lainnya. Masalah ini sudah banyak terjadi dan memprihatinkan, sejauh ini aborsi seringkali dilakukan oleh orang-orang yang tidak memiliki lesensi medis untuk penanganan aborsi, seperti misalnya dukun tradisional 
atau ahli pijat yang menggunakan cara pemijatan untuk menggugurkan kandungan dan tenaga kesehatan yang belum memegang izin atas kegiatan aborsi. Selain itu aborsi juga dapat dilakukan dengan obat-obatan atau ramuan yang dapat meluruhkan janin di dalam kandungan. Keprihatinan itu bukan tanpa alasan, karena sejauh ini tindakan aborsi dapat menimbulkan bahaya dan efek negatif bagi kesehatan dan nyawa perempuan yang melakukan aborsi tersebut. Mambahas persoalan aborsi sudah bukan rahasia umum dan hal yang tabu lagi untuk di perbincangkan, karena peristiwanya dapat terjadi dimana-mana dan bisa saja dilakukan secara ilegal. Dari sekian banyak perempuan yang melakukan aborsi memilih aborsi yang dilakukan oleh tenaga yang tidak terlatih dan tidak memiliki lesensi di bidang kedokteran maupun kesehatan untuk melakukan aborsi. Hal ini disebabkan oleh biaya aborsi yang dilakukan oleh tenaga yang tidak ahli dalam bidangnya cenderung lebih murah bila dibandingkan dengan biaya aborsi yang dilakukan oleh tenaga kesehatan yang lebih profesional.

Dalam hukum positif di Indonesia, ketentuan berkaitan dengan masalah aborsi ini diatur dalam beberapa peraturan perundang-undangan, diantaranya adalah Kitab Undang-undang Hukum Pidana (KUHP), Undang-Undang Kesehatan, dan PP Kesehatan Reproduksi. Dalam KUHP Pasal 346, Pasal 347, Pasal 348, Pasal 349, dan Pasal 350 KUHP . Yang pada intinya pasal-pasal tersebut menyatakan bahwa tuntutan dikenakan bagi orang-orang yang melakukan pengguguran kandungan ataupun orang-orang yang membantu melakukan baik secara langsung maupun tidak langsung. ${ }^{1}$ Namun terdapat beberapa pengecualian yang diatur dalam Undang-Undang Kesehatan Tahun 2009 terhadap larangan melakukan pengguguran kandungan. Dengan adanya pengecualian terhadap larangan aborsi, menimbulkan konflik norma dengan KUHP yang pada dasarnya melarang adanya aborsi. Namun demikian berdasarkan asas Lex Specialis Derogat legi generalis, bahwa apabila terjadi pertentangan antara aturan yang khusus dan aturan yang umum, maka yang digunakan adalah aturan yang mengatur lebih khusus. Dalam hal ini pengaturan

${ }^{1}$ Dewi Indraswati, Fenomena Kawin Muda dan Aborsi: Gambaran Kasus (Sinar Grafika 2011).[132]. 
khusus mengenai aborsi ialah Undang-Undang Nomor 36 Tahun 2009 tentang Kesehatan, aturan terkait aborsi didalam KUHP dikalahkan oleh pengecualian yang diatur secara khusus didalam Undang-Undang Nomor 36 Tahun 2009 tentang Kesehatan. Undang-Undang Nomor 36 Tahun 2009 tentang Kesehatan pasal 75 ayat (1) menyatakan bahwa tindakan Aborsi dilarang. Namun didalam pasal 75 ayat (2) dijelaskan adanya keadaan yang dikecualikan dari larangan aborsi. Keadaan yang dimaksud ialah, kedaruratan medis dan kehamilan akibat pemerkosaan. Berdasarkan pengecualian larangan aborsi tersebut pada pasal 76 huruf $\mathrm{b}$ bahwa pada intinya aborsi tersebut hanya dapat dilakukan oleh tenaga kesehatan yang memiliki keterampilan dan kewenangan yang memiliki sertifikat yang ditetapkan oleh menteri. Tenaga kesehatan tersebut dalam melakukan tugasnya wajib memiliki pengetahuan dan keterampilan di bidang kesehatan yang dinyatakan dengan ijazah dari lembaga pendidikan. ${ }^{2}$ Dalam Ketentuan Umum pasal 1 angka 6 menjelaskan bahwa Tenaga Kesehatan adalah setiap orang yang mengabdikan diri dalam bidang kesehatan serta memiliki pengetahuan dan/atau keterampilan melalui pendidikan di bidang kesehatan yang untuk jenis tertentu memerlukan kewenangan untuk melakukan upaya kesehatan. Berdasarkan pada Pasal 11 ayat (1) Undang-undang Nomor 36 Tahun 2014 Tentang Tenaga Kesehatan dibedakan menjadi beberapa macam. Keadaan seperti di atas yang membuat banyak timbul praktik aborsi gelap yang dilakukan baik oleh tenaga kesehatan formal maupun tenaga kesehatan informal dan yang sesuai standart operasional medis maupun yang tidak sesuai standart operasional yang di tetapkan oleh menteri. Padahal hak tenaga kesehatan adalah hak untuk bekerja menurut standart medis dan hak menolak melaksanakan tindakan medis karena secara profesional tidak dapat mempertanggungjawabkan. ${ }^{3}$ Yang menjadi persoalan selanjutnya mengenai ketidakjelasan mengenai siapa saja tenaga kesehatan yang dapat melakukan aborsi legal. Undang-Undang Nomor 36 Tahun 2009 tersebut tidak menjelaskan secara jelas bagaimana ketentuan mengenai

2 Harmien Hadiati Koeswadji, Hukum Kedokteran Studi Tentang Hubungan Hukum Dalam Mana Dokter Sebagai Salah Satu Pihak (PT.Citra Aditya Bakti 1998).[103].

3 Hendrik, Etika dan Hukum Kesehatan (Buku Kedokteran EGC 2012).[45]. 
tenaga kesehatan yang berwenang melakukan tindakan aborsi. Aborsi juga turut diatur dalam Peraturan Pemerintah Nomor 61 Tahun 2014 Kesehatan Reproduksi. Pasal 35 ayat (1) PP tersebut menyatakan bahwa aborsi yang didasarkan pada indikasi keadaan medis dan kehamilan akibat pemerkosaan harus dilakukan dengan aman, bermutu dan bertanggung jawab. Ayat selanjutnya dalam pasal 35 ayat (2) menyebutkan hal apa saja yang harus dilakukan agar aborsi dapat dikategorikan sebagai tindakan aman, bermutu dan bertanggung jawab, hal tersebut antara lain dilakukan oleh dokter yang sesuai dengan standart. Berdasarkan syarat yang telah di sebutkan sebelumnya, tindakan aborsi yang aman, bermutu dan bertanggung jawab hanya dapat dilakukan oleh dokter yang memiliki standart kemampuan untuk melakukan aborsi. Yang kemudian dijelaskan dalam pasal 36 PP tersebut, bahwa dokter yang melakukan tindakan aborsi harus mendapatkan pelatihan yang terakreditasi dan dibuktikan dengan sertifikat. Namun demikian, PP tersebut tidak memberikan penjelasan secara spesifik dokter yang menangani khusus tindakan aborsi dan tidak ada ketentuan lain mengenai tenaga kesehatan selain tenaga medis yang dapat melakukan tindakan aborsi, padahal selama ini di dalam prakek kasuskasus aborsi dilakukan oleh tenaga kesehatan yang bukan dokter misalnya saja perawat, bidan, bahkan tenaga pengobatan tradisional seperti dukun.

Apakah tenaga kesehatan yang disebutkan pada undang-undang tenaga kesehatan memiliki kewenangan melakukan tindakan aborsi legal.

\section{Rumusan Masalah}

1. Apakah tenaga kesehatan selain dokter mempunyai kewenangan melakukan aborsi legal?

2. Sanksi yang dapat diterapkan bagi tenaga kesehatan yang tidak berwenang melakukan aborsi legal?

\section{Pendekatan Masalah}

Pendekatan yang digunakan dalam penulisan penelitian hukum ini adalah pendekatan PerUndang - undangan (Statute Approach) yakni pendekatan dengan 
menggunakan legislasi dan regulasi, ${ }^{4}$ Pendekatan Konseptual (Conceptual Approach) yakni pendekatan yang merujuk prinsip - prinsip hukum melalui pandangan - pandangan dan doktrin - doktrin yang ada. ${ }^{5}$

\section{Tenaga Kesehatan selain Dokter yang mempunyai Kewenangan melakukan} Aborsi Legal

Kamus Besar Bahasa Indonesia, aborsi adalah terpencarnya embrio yang tidak mungkin lagi hidup sebelum habis bulan keempat dari kehamilan. Aborsi diartikan sebagai pengguguran kandungan, yaitu dikeluarkannya janin sebelum waktunya, baik itu secara sengaja maupun tidak. Aborsi sebagai tindakan terminasi kehamilan yang tidak diinginkan melalui metode obat-obat atau bedah. ${ }^{6}$ Biasanya aborsi dilakukan saat janin masih berusia muda (sebelum bulan ke empat masa kehamilan). Menurut Dorland (2002), aborsi adalah pengeluaran hasil kontrasepsi secara premature dari uterus-embrio, atau fetus yang belum dapat hidup. Dalam Ilmu Kedokteran, aborsi diartikan sebagai pengeluaran alat konsepsi dari Rahim sebelum janin dapat hidup diluar (usia kurang dari 20 minggu). ${ }^{7}$ Menurut Hukum Pidana, Aborsi adalah menggugurkan atau mematikan kandungan seorang wanita, tanpa ada batasan usaia kehamilan, sedangkan dalan Undang-Undang 36 Tahun 2009 tentang Kesehta, batasan umur abaorsi yaitu sebelum 6 minggu untuk korban pemerkosaan, untuk aborsi dengan indikasi medis tidak ada batas. Dapat disimpulkan bahwa aborsi adalah penghentian kehamilan janin dapat hidup diluar kandungan dengan usia kehamilan kurang dari 28 minggu. Dilihat dari tujuan dilakukannya, Aborsi dibagi menjadi 2 macam, yaitu: ${ }^{8}$

1. Abortus Spontaneus yaitu aborsi yang terjadi dengan tidak didahului oleh faktor-faktor mekanis ataupun medicinalis, semata-mata disebabkan oleh

4 Peter Mahmud Marzuki, Penelitian Hukum Edisi Revisi (Prenadamedia Group 2016).[47].

5 ibid.[133].

6 Rahmi Yuningsih, 'Legalisasi Aborsi Korban Perkosaan dalam Info Singkat Kesejahteraan, Kajian Singkat Terhadap Isu-isu Terkini’ (2014), 6 E-Jurnal Katalogis.[10].

7 ibid.[7].

8 Marcel Seran, Anna Maria Wahyu, Dilema Etika dan Hukum Dalam Pelayanan Medis (Mandar Maju 2010).[61]. 
faktor alamiah.

2. Abortus Provocatus yaitu aborsi yang disengaja baik dengan menggunakan obat-obatan maupun alat-alat. Aborsi jenis ini dibedakan lagi menjadi:

a. Abortus provocatus medicinalis yaitu aborsi yang dilakukan karena adanya indikasi medis untuk menyelamatkan nyawa ibu si janin, atau menghindarkan si ibu dari kerusakan fatal pada kesehatan/tubuhnya yang tidak bisa dikembalikan lagi;

b. Abortus provocatus criminalis yaitu aborsi yang dilakukan sebelum janin bisa hidup di luar kandungan dengan alasan-alasan lain selain therapeutic, dan dilarang oleh hukum.

Undang-Undang Nomor 36 Tahun 2009 Tentang Kesehatan. Pada pasal 75 dan 76 , kembali menegaskan bahwa pada dasarnya melarang adanya praktik aborsi (paal 75 ayat 1). Meski demikian larangan tersebut dikecualikan apabila ada:

1. Indikasi kedaruratan medis yang mengancam nyawa ibu dan/atau janin, yang menderita penyakit genetic berat dan/atau cacat bawaan, maupun yang tisak dapat diperbaiki sehingga menyulitkan bayi tersebut hidup diluar kandungan; atau

2. Kehamilan akibat pemerkosaan yang dapat menyebabkan trauma psikologis bagi korban pemerkosaan

Namun demikian berdasarkan asas Lex Specialis Derogat Legi Generalis, bahwa apabila terjadi pertentangan antara aturan yang khusus dan aturan yang umum, maka yang digunakan adalah aturan yang mengatur lebih khusus. Dalam hal ini pengaturan khusus mengenai aborsi ialah Undang-Undang Nomor 36 Tahun 2009 tentang Kesehatan, aturan terkait aborsi didalam KUHP dikalahkan oleh pengecualian yang diatur secara khusus didalam Undang-Undang Nomor 36 Tahun 2009 tentang Kesehatan. Pasal 76 Undang-Undang Nomor 36 Tahun 2009 Tentang Kesehatan juga mengatur bahwa aborsi sebagaimana dimaksud dalam pasal 75 hanya dapat dilakukan:

1. Sebelum kehamilan berumur 6 minggu dihitung dari hari pertama haid terakhir, kecuali dalam hal kedaruratan medis;

2. Oleh tenaga kesehatan yang memiliki keterampilan dan kewenangan yang 
memiliki sertifikat yang di tetapkan oleh menteri;

3. Dengan persetujuan ibu hamil yang bersangkutan;

4. Dngan izin suami, kecuali korban pemerkosaan; dan

5. Penyedia layanan kesehatan yang memenuhi syarat yang di tetapkan oleh Menteri.

Kewenangan Tenaga Kesehatan menurut Undang- undang Nomor 36 Tahun 2014, diatur dalam ketentuan Pasal 62, yang berbunyi : Tenaga kesehatan dalam menjalankan praktek harus dilakukan sesuai dengan kewenangan yang didasarkan pada kompetensi yang dimilikinya, Jenis tenaga kesehatan tertentu yang memiliki lebih dari satu jenjang pendidikan memiliki kewenangan profesi sesuai dengan lingkup dan tingkat kompetensi, Ketentuan lebih lanjut mengenai kewenangan profesi diatur dengan Peraturan Menteri. Yang dimakasud dengan kewenangan berdasarkan kompetensi adalah kewenangan untuk melakukan pelayanan kesehatan secara mandiri sesuai dengan lingkup dan tingkat kompetensinya, yaitu

a. apoteker memiliki kewenangan untuk melakukan pekerjaan kefarmasian;

b. perawat memiliki kewenangan untuk melakukan asuhan keperawatan secara mandiri dan komperhensif serta tindakan kolaborasi keperawatan dengan Tenaga kesehatan lain sesuai dengan kualifikasinya; dan

c. bidan memiliki kewenangan untuk melakukan pelayanan kesehatan ibu, pelayanan kesehatan anak, dan pelayanan kesehatan reproduksi perempuan dan keluarga berencana. Mengenai pelimpahan Tindakan, dalam melakukan pelayanan kesehatan

Tenaga Kesehatan dapat Menerima Pelimpahan Tindakan medis dari tenaga medis yaitu Dokter, Dokter Gigi, Dokter Spesialis, Dokter Gigi Spesialis. Dapat disimpulkan bahwa aborsi dikatakan Legal apabila memenuhi syarat dan ketentuan berdasarkan pasal 75 dan 76 Undang-Undang Nomor 36 Tahun 2009 Tentang Kesehatan. Peraturan Menteri Kesehatan Nomor 3 Tahun 2016 Tentang Pelatihan dan Penyelenggaraan Pelayanan Aborsi Atas Indikasi Kedaruratan Medis dan Kehamilan Akibat Pemerkosaan. Berdasarkan Peraturan Menteri tersebut Tidanakan aborsi legal itu sendiri dapat ditentukan oleh tim kelayakan aborsi dimana tim itu sendiri paling sedikit terdiri dari 2 orang tenaga kesehatan yang diketahui oleh dokter yang 
memiliki kompetensi dan kewenangan. Dokter yang melakukan aborsi legal harus mendapatkan pelatihan oleh penyelenggara pelatihan yang terakreditasi dimana pelatihan itu berisikan pembelajaran dalam rangka meningkatkan pengetahuan, keterampilan dan perilaku peserta pelatihan dalam melaksanakan praktik aborsi sesuai ketentuan yang berlaku yaitu aman, bermutu dan bertanggung jawab. Peserta pelatihan dalam hal ini hanya diikuti oleh dokter yang ditetapkan oleh kepala Dinas Kesehatan Kabupaten/Kota. Peserta yang telah mengikuti pelatihan dalam hal ini adalah dokter berhak mendapatkan sertifikat pelatihan yang dikeluarkan oleh pemerintah pusat. Sertifikat pelatihan tersebut merupakan bentuk pengakuan untuk memberikan pelayanan aborsi aman, bermutu dan bertanggung jawab.sertifikat pelatihan hanya berlaku selama 5 tahun dan dapat diperbaharui dengan melakukan pelatihan kembali. Praktik pelayanan aborsi yang aman, bermutu dan bertanggung jawab harus diselenggarakan di fasilitas pelayanan kesehatan yang ditetapkan oleh Menteri yaitu puskesmas, klinik pratama, klinik utama atau yang setara dan rumah sakit yang memiliki Dokter Obsetetri dan ginekologi yang telah melakukan pelatihan. Dalam hal ini dalam praktik penyelenggaraan aborsi legal hanya dapat dilakukan oleh dokter saja yang telah mendapatkan sertifikat pelatihan, tidak boleh dilakukan oleh tenaga kesehatan lain.

\section{Sanksi yang dapat Diterapkan bagi Tenaga Kesehatan yang Berwenang Melakukan Aborsi Legal}

Istilah Etika sesungguhnya memiliki banyak arti, secara etimologi istilah etika berasal dari kata Yunani Ethos dan Ethikos. Ethos berarti sifat, watak, kebiasaan. Ethikos berarti susila, keadaban, atau kelakuan dan tingkah laku yang baik. Kata ini idientik dengan kata moral yang berasal dari Bahasa Latin Mores yang berarti adat istiadat, kebiasaan, watak, kelakuan, dan cara hidup. Berkaitan dengan etika Profesi Tenaga Kesehatan, dapat dikatakan bahwa pengertian etika profesi tenaga kesehatan adalah kumpulan norma-norma atau kaidah sebagai standart perilaku bertindak bagi profesi tenaga kesehatan dalam melayani kesehatan masyarakat. Adapun yang dimaksud dengan norma/kaidah 
atau standart perilaku/pedoman adalah "kode etik profesi". Kode Etik Profesi dibuat agar setiap profesi kesehatan senantiasa berpegang teguh dan berperilaku sesuai dengan kehormatan profesinya, maka sebelum menjalankan tugas dan profesinya diwajibkan untuk mengangkat sumpah sebagai janji profesi baik untuk umum (kemanusiaan), untuk klien atau pasien, teman sejawat, dan untuk diri sendiri. Ditinjau dari segi etik, aborsi adalah perbuatan yang melanggar kode etik kedokteran seperti yang tertuang di dalam Surat Keputusan Pengurus Besar Ikatan Dokter Indonesia Nomer 221/PB/A.4/04/2002 Tentang Penetapan Kode Etik Kedokteran Indonesia pasal 7d bahwa dokter bersumpah akan melindungi setiap hidup insani sejak dalam pembuahan. Oleh karena itu aborsi secara etis tidak dibenarkan. Kode Etik itu sendiri berisikan suatu kontrak kewajiban moral antara dokter dengan kelompok seprofesinya. Meskipun kewajiban tersebut bukan merupakan kewajiban hukum, namun kewajiban moral untuk melindungi setiap hidup insani sejak pembuahan, jika dilanggar akan masuk ke pelanggaran kewajiban hukum. Pelanggaran tersebut muncul apabila dokter melakukan aborsi yang mana tindakan tersebut melanggar kode etik khususnya pelanggaran etikolegal yang mana tidak sesuai dengan syarat yang ditentukan dalam pasal 75 ayat (2) Undang-Undang Kesehatan, maka dapat dipidana sebagaimana diatur pasal 194 Undang-Undang Kesehatan 2009. Pelanggaran etik tidak menimbulkan sanksi formal bagi pelakunya, sehingga terhadap pelakunya hanya diberikan tuntutan oleh Majelis Kehormatan Etik Kedokteran. Secara maksimal mungkin Majelis Kehormatan Etik Kedokteran memberikan usul ke Kanwil Depkes Provinsi atau Depkes untuk memberikan tindakan sebagai langkah pencegahan terhadap kemungkinan pengulangan pelanggaran yang sama. Sanksi etik yang dapat diberikan oleh Majelis Kehormatan Etik Kedokteran terbagi 4 kategori, yaitu Kategori 1 (Satu), bersifat murni Pembinaan. Kategori Dua, bersifat Penginsafan tanpa pemberhentian keanggotaan, kategori 3 bersifat Penginsafan dengan pemberhentian keanggotaan sementara, dan kategori 4 bersifat pemberhentian keanggotaan tetap. 
1. Sanksi Kategori 1 (Satu) di antaranya sebagai berikut:
a. Membuat refleksi diri secara tertulis;
b. Mengikuti workshop etika yang ditentukan MKEK;
c. Mengikuti modul etik yang sedang berjalan di FK yang ditunjuk oleh MKEK;
d. Mengikuti program magang bersama panutan selama 3(tiga) bulan;
e. Kerja sosial pengabdian profesi di institusi kesehatan yang ditunjuk MKEK tidak lebih dari tiga bulan.

2. Sanksi kategori 2 di antaranya sebagai berikut:
a. Rekomendasi pemberhentian jabatan tertentu kepada pihak yang berwenang;
b. Pemberhentian dari jabatan di IDI dan organisasi di bawah IDI serta pelarangan menjabat di IDI dan organisasi di bawah IDI untuk satu periode kepengurusan;
c. Kerja sosial pengabdian profesi di institusi kesehatan yang ditunjuk MKEK dalam kurun waktu 6-12 bulan;
d. Mengikuti program magang bersama panutan selama 6-12 bulan.

3. Sanksi kategori 3 (tiga), berupa pemberhentian keanggotaan sementara keanggotaan beserta pencabutan sementara hak dan kewenangan profesi sebagai dokter di Indonesia sekurang-kurangnya 12 bulan. Hilangnya hak dan kewenangan tersebut dapat berimplikasi pada:

a. Kehilangan hak dan kewenangan melakukan praktik kedokteran, termasuk dicabut sementara seluruh rekomendasi izin praktik yang kewenangan untuk itu akan ditindaklanjuti kemudian oleh otoritas penerbit izin praktik agar menonaktifkan sementara Surat izin praktik yang bersangkutan;

b. Kehilangan hak dan kewenangan menjadi pengurus dan anggota IDI dan seluruh organisasi di bawah IDI termasuk Perhimpunan Dokter Spesialis (PDSp) atau Perhimpunan Dokter Pelayanan Primer (PDPP) yang kewenangan untuk itu akan ditindaklanjuti kemudian oleh jajaran IDI, PDSp, PDPP, dan organisasi lain di bawah IDI;

c. Kehilangan hak dan kewenangan menyandang suatu jabatan publik yang menyaratkan dijabat seorang dokter aktif yang kewenangan untuk itu akan ditindaklanjuti kemudian oleh instansi/organisasi terkait;

d. Surat Tanda Registrasi dan status di Konsil Kedokteran Indonesia (KKI) menjadi non-aktif yang kewenangan untuk itu akan ditindaklanjuti kemudian oleh KKI;

e. Sanksi kategori 4 (empat) berupa pemberhentian keanggotaan tetap yang juga bermakna hilangnya seluruh hak dan kewenangan secara tetap.

Sanksi administratif adalah sanksi yang dikenakan terhadap pelanggaran administrasi atau ketentuan yang bersifat administratif. Umumnya sanksi 
administrasi berupa peringatan, denda, pencabutan/pembekuaan izin tertentu. Teguran, sanksi ini bisa berupa teguran secara lisan dan tulisan. Penjatuhan teguran sanksi ini kepada pihak penerima sanksi harus diberitahukan jenis pelanggarannya dan sekaligus pemberitahuan pemberian sanksi, agar penerima sanksi mengetahui jenis kesalahannya. Jenis sanksi ini bersifat ringan dan kepada pihak yang ditegur masih diberi kesempatan untuk memperbaiki diri. Pembekuan hingga pencabutan sertifikat dan/atau izin pengertian untuk jangka waktu sementara atau selamanya. Jika untuk sementara mempunyai batas waktu dan bila batas waktu telah terlewati maka sanksi sudah dianggap selesai. Denda, besar kecilnya denda akan ditentukan oleh hukum yang mengaturnya, karema setiap ketentuan mempunyai dasar hukum dan ketentuan masing-masing. Pertanggungjawaban dalam hukum pidana dalam bahasa belanda disebut dengan "Strafrectterlijke Toerekening" dan dalam bahasa inggris "criminal resposbility" atau "criminal liability". 9 Di Hukum Pidana juga terdapat asas dalam pertanggungjawaban pidana yaitu Geen Straf Zonder Schuld; Actus Non Facit Reum Nisi Mens Sir Rea yang artinya tiada pidana tanpa kesalahan. ${ }^{10}$ Asas ini tidak tersebut dalam hukum tertulis tapi dalam hukum yang tidak tertulis di Indonesia asas ini berlaku. Menurut Kamus Besar Bahasa Indonesia (KBBI) yang dimaksud dengan tanggung jawab adalah suatu keadaan wajib yang harus ditanggung segala sesuatunya dan bila terjadi sesuatu boleh dituntut, dipersalahkan dan juga diperkarakan. Menurut hukum, tanggung jawab adalah suatu akibat atas konsekuensi kebebasan seorang tentang perbuatannya yang berkaitan dengan etika atau moral dalam melakukan suatu perbuatan. ${ }^{11}$ Selanjutnya menurut Titik Triwulan pertanggungjawaban harus mempunyai dasar, yaitu hal yang menyebabkan timbulnya hak hukum bagi seorang untuk menuntut orang lain sekaligus berupa hal yang melahirkan kewajiban hukum orang lain untuk memberi

9 Moeljatno, Perbuatan Pidana Dan Pertanggungjawaban Dalam Hukum Pidana (Bina Aksara 1983).[22].

${ }^{10}$ Moeljatno, Asas-Asas Hukum Pidana, (Rineka Cipta 2008).[165].

11 Soekidjo Notoatmojo, Etika dan Hukum Kesehatan (Rineka Cipta 2010).[45]. 
pertanggungjawabannya. ${ }^{12}$ Terdapat hal-hal penting terkait Pertanggungjawaban pidana yaitu: ${ }^{13}$

1. Unsur Kesalahan:

a. Melakukan tindak pidana;

b. Diatas umur tertentu dan mampu bertanggung jawab;

c. Dengan kesengajaan dan kealpaan;

d. Tidak ada alasan pemaaf.

2. Bentuk atau corak kesalahan
a. Dengan sengaja;
b. Dengan kealpaan.

Terdapat 2 jenis sanksi pidana menurut pasal 10 KUHP terdiri dari pidana pokok dan pidana tambahan. Pidana pokok terdiri dari pidana mati, pidana penjara, pidana kurungan, dan pidana denda. Sedangkan pidana tamabahan terdiri dari pidana pencabutan hak - hak tertentu, perampasan barang - barang tertentu, dan pengunguman putusan hakim. Antara pidana pokok dan pidana tambahan dapat berdiri sendiri dan dapat juga sebagai tambahan. Karena sifatnya tambahan hanya berfungsi sebagai penambah bisa diterapkan dan ada pula yang tidak bisa diterapkan. Pidana pokok bisa berdiri sendiri, tidak ada kewajiban harus disertai pidana tambahan. Artinya pidana pokok KUHP tidak boleh dijatuhkan bersamaan, misalnya pidana penjara dan denda, sedangkan ancaman pidana dijatuhkan maksimal atau selama-lamanya, system penjatuhan pidana yang dimuat dalam KUHP berbeda dengan system pidana yang ada Undang-Undang Nomor 36 Tahun 2009 Tentang Kesehatan, dimana system penjatuhan pidananya adalah kumulatif. Berkaitan dengan pertanggungjawaban pidana tindakan aborsi dapat dilihat di dalam Bab XIV Buku ke II KUHP tentang Kejahatan Terhadap Nyawa khususnya pasal Pasal 346, Pasal 347, Pasal 348, Pasal 349, dan Pasal. Dalam pasal-pasal tersebut secara singkat dapat dijelaskan bahwa yang dapat dihukum, menurut KUHP dalam kasus aborsi ini adalah:

12 Titik Triwulan dan Shinta Febrian, Perlindungan Hukum bagi Pasien (Prestasi Pustaka 2010).[48].

${ }_{13}$ Didik Endro Purwoleksono, Hukum Pidana (Airlangga University Press 2013).[63]. 
a. Pelaksanaan aborsi, yaitu tenaga kesehatan atau dukun atau orang lain dengan hukuman maksimal 4 tahun ditambah sepertiga dan bisa juga dicabut hak untuk berpraktek;

b. Wanita yang menggugurkan kandungannya, dengan hukuman maksimal tahun penjara;

c. Orang-orang yang terlibat langsung dan menjadi penyebab terjadinya aborsi itu dihukum dengan hukuman bervariasi.

Berkaitan dengan aborsi berdasarkan Undang-Undang Nomor 36 Tahun 2009 tentang Kesehatan, aborsi hanya boleh dilaksanakan berdasarkan ketentuan pasal 75 ayat (2) yaitu atas dasar indikasi kedaruratan medis dan kehamilan akibat pemerkosaan. Aborsi tersebut hanya dapat dilakukan oleh dokter yang memiliki kewenangan dan memiliki sertifikat khusus yang di dapat dari pelatihan yang diselenggarakan oleh menteri, apabila tidak sesuai dengan ketentuan sebagai mana yang dimaksud dalam pasal 75 ayat (2) akan dikenakan pidana bagi orang yang dengan sengaja melakukan tindakan aborsi tidak sesuai dengan ketentuan sebagaimana yang dimaksud pasal 75 ayat 2 yaitu dikenakan pidana penjara 10 tahun dan denda paling banyak Rp 1.000.000.000,00 (satu miliar) sesuai dengan pasal 194 Undang - Undang Kesehatan Nomor 36 Tahun 2009. Selain UndangUndang Nomer 36 Tahun 2009, pelaku aborsi yang mempunyai kualifikasi sebagai tenaga medis (dokter dan dokter gigi) dpaat juga diberi sanksi seperti yang diatur dalam undang-Undang Nomer 29 Tahun 2004 tentang Praktek Kedokteran, sedangkan bagi tenaga kesehatan selain dokter dapat di tetapkanaturan UndangUndang Nomor 36 tahun 2014 Tentang Tenaga Kesehatan, atau bagi orang lain yang terlibat dapat diterapkan ketentuan yang diatur dalam KUHP.

\section{Kesimpulan}

Pada prisnipnya Aborsi berdasarkan Undang-Undang Nomor 36 Tahun 2009 tentang Kesehatan jo. Peraturan Menteri Kesehatan Nomor 3 Tahun 2016 Tentang Pelatihan dan Penyelenggaraan Pelayanan Aborsi Atas Indikasi Kedaruratan Medis dan Kehamilan Akibat Pemerkosaan tidanakan aborsi legal hanya boleh dilakukan 
oleh Dokter yang mendapatkan pelatihan oleh penyelenggara pelatihan Praktik pelayanan aborsi yang aman, bermutu dan bertanggung jawab harus diselenggarakan di fasilitas pelayanan kesehatan yang ditetapkan oleh Menteri yaitu puskesmas, klinik pratama, klinik utama atau yang setara dan rumah sakit yang memiliki Dokter Obsetetri dan Ginekologi yang telah melakukan pelatihan. Dalam hal ini dalam praktik penyelenggaraan aborsi legal hanya dapat dilakukan oleh dokter saja yang telah mendapatkan sertifikat pelatihan, tidak boleh dilakukan oleh tenaga kesehatan lain. Dalam penyelesaian kasus aborsi legal, apabila tidak dilakukan berdasarkan peraturan yang di tentukan maka akan terkena sanksi etik dan pidana berupa berupa teguran lisan, peringatan tertulis, pencabutan izin, dan denda administratif. Dan sanksi pidana berupa hukuman penjara pidana penjara paling lama 10 tahun dan denda 10 miliar.

\section{Daftar Bacaan}

\section{Buku}

Dewi Indraswati, Fenomena Kawin Muda dan Aborsi: Gambaran Kasus (Sinar Grafika 2011).

Didik Endro Purwoleksono, Hukum Pidana (Airlangga University Press 2013).

Harmien Hadiati Koeswadji, Hukum Kedokteran Studi Tentang Hubungan Hukum Dalam Mana Dokter Sebagai Salah Satu Pihak (PT.Citra Aditya Bakti 1998).

Hendrik, Etika dan Hukum Kesehatan (Buku Kedokteran EGC 2012).

Marcel Seran, Anna Maria Wahyu, Dilema Etika dan Hukum Dalam Pelayanan Medis (Mandar Maju 2010).

Moeljatno, Perbuatan Pidana Dan Pertanggungjawaban Dalam Hukum Pidana (Bina Aksara 1983).

Moeljatno, Asas-Asas Hukum Pidana (Rineka Cipta 2008).

Peter Mahmud Marzuki, Penelitian Hukum Edisi Revisi (Prenadamedia Group 2016).

Soekidjo Notoatmojo, Etika dan Hukum Kesehatan (Rineka Cipta 2010). 
Titik Triwulan dan Shinta Febrian, Perlindungan Hukum bagi Pasien (Prestasi Pustaka 2010).

\section{Jurnal}

Rahmi Yuningsih, 'Legalisasi Aborsi Korban Perkosaan dalam Info Singkat Kesejahteraan, 'Kajian Singkat Terhadap Isu-isu Terkini' (2014) 6 E-Jurnal Katalogis 
1920 Risa Noviariyani: Tenaga Kesehatan yang Berwenang

--halaman ini sengaja dibiarkan kosong-- 